Bangladesh J. Bot. 44(1): 103-110, 2015 (March)

\title{
STATUS AND CONTAMINATION LEVEL OF THE WASTEWATER OF GEBENG INDUSTRIAL ESTATE, PAHANG, MALAYSIA
}

\author{
Md Abdus Sobahan, Sujaul Islam Mir* and Md Abdul Karim ${ }^{1}$ \\ Faculty of Civil Engineering and Earth Resources, University Malaysia Pahang, Lebuhraya \\ Tun Razak, 26300, Gambang Kuantan, Pahang, Malaysia
}

Key words: Status, Gebeng, Wastewater, Contaminants, Heavy metals

\begin{abstract}
The $\mathrm{pH}$ of the water of the studied stations was slightly acidic to neutral, while EC was included within recommended standard. The contamination intensity, pollution level, classification of water indicated that the wastewater having higher contamination level, especially, BOD, $\mathrm{COD}, \mathrm{NH}_{3}-\mathrm{N}, \mathrm{PO}_{4}, \mathrm{~Pb}, \mathrm{Cd}, \mathrm{Cr}, \mathrm{Cu}, \mathrm{Co}, \mathrm{Ni}$ and $\mathrm{Hg}$ concentration were high in all samples with lower DO value. The high COD content indicated that the wastewater of Gebeng area contains higher wastes. However, the results were differed on the basis of seasons and types of industries. It was also found that $\mathrm{Pb}$ and $\mathrm{Hg}$ concentrations were higher in wet season in comparison to dry, while $\mathrm{Cd}, \mathrm{Co}, \mathrm{Cr}, \mathrm{Cu}, \mathrm{Zn}, \mathrm{Ni}, \mathrm{Ba}$ and As concentrations were higher in dry season in comparison to wet. All sampling sites were categorized as highly polluted.
\end{abstract}

\section{Introduction}

The population of the world has been increasing rapidly and to cope up with this a huge amount of food, energy and employments are required. Industrialization is the easiest way to meet up those demands. Nevertheless, the disposal of industrial wastewater is a great problem throughout the world. It may contain heavy metals as well as other pollutants (Abramov et al. 2014). The dumping of wastewater from the industry could destroy the sustainable industrial approach (Changhao and Zhans 2013).

Gebeng is a rapidly growing industrial area in Malaysia that has been reported the biggest sources of water pollution due to food and beverage, chemical, textiles, paper, palm oil and rubber processing industries. Such rapid development of industries however has increased the pollution level in surrounding water sheds. Because, most of the wastewater released from the industries contains contaminants and dumped into the surface water (Sujaul et al. 2013). The wastewater of Gebeng industrial estate contains pollutants, viz. higher BOD, COD, TSS and heavy metals (Syukor et al. 2013). Considering the above mentioned problems the present work was undertaken to detect the pollution level and the condition of the water of the study area.

\section{Materials and Methods}

Sampling sites were selected from Gebeng industrial estate considering industrial types, topography and discharge points of wastewater (Table 1). Water samples were collected in both dry (July - September 2013) and wet (November - January 2013 - 2014) seasons from 6 sampling sites viz. S 1 - S 6. Water samples were collected at $10 \mathrm{~cm}$ depth from the surface using $500 \mathrm{ml}$ HDPE (High Density Polyethylene) bottles those were kept into icebox immediately after sampling and were preserved at $<4^{\circ} \mathrm{C}$ until analysis. Temperature, DO, EC, pH, turbidity, BOD, TSS and TDS were determined in situ by using YSI 6600 (YSI Incorporate, USA) metre. Ammoniacal-nitrogen, nitrate, sulfate, phosphate and COD were determined by HACH kit (HACH DR 2500, USA), while heavy metals were determined by ICPMS (Inductively coupled

*Author for correspondence: <sujaulbd@gmail.com>. ${ }^{2}$ Department of Botany, University of Dhaka, Dhaka 1000, Bangladesh. 
plasma mass spectrometry) (APHA 2013). Furthermore, TSS was analyzed gravimetrically after filtration with an adequate sample through a glass fiber filter and drying at $105^{\circ} \mathrm{C}$.

Table 1. Description of the sampling sites.

\begin{tabular}{|c|c|c|}
\hline Sites & Location & Descriptions \\
\hline S 1 & $03^{\circ} 59^{\prime} 37^{\prime \prime N} 103^{\circ} 24^{\prime} 46^{\prime \prime E}$ & $\begin{array}{l}\text { Hope Mining (Coal Mining), Yanox (M), Sdn. Bhd. (Wood } \\
\text { Processing), Southern Steel Mesh. Sdn. Bhd. }\end{array}$ \\
\hline S 2 & $03^{\circ} 59^{\prime} 16^{\prime \prime} \mathrm{N} 103^{\circ} 23^{\prime} 18^{\prime \prime} \mathrm{E}$ & $\begin{array}{l}\text { Opposite of East chemicals \& Eco tower (Lynax) Sdn. Bhd. Gebeng } \\
\text { Industrial area. }\end{array}$ \\
\hline S 3 & $03^{\circ} 59^{\prime} 1 " \mathrm{~N} 103^{\circ} 22^{\prime} 40^{\prime \prime} \mathrm{E}$ & Opposite of Kaneka and adjacent to Flexysl, Gebeng Industrial area \\
\hline S 4 & $03^{\circ} 58^{\prime} 34^{\prime \prime} \mathrm{N} 103^{\circ} 23^{\prime} 17 " \mathrm{E}$ & Near MTBE, BP chemicals \\
\hline S 5 & $03^{\circ} 583^{\prime} 33^{\prime \prime} \mathrm{N} 103^{\circ} 23^{\prime} 24 " \mathrm{E}$ & $\begin{array}{l}\text { Near Asturi Metal Builders, Mieco Chips board Berhad, KNM } \\
\text { process Systems Sdn. Bhd. Borsig, Boiler System. }\end{array}$ \\
\hline S 6 & $03^{\circ} 57^{\prime} 40^{\prime \prime} \mathrm{N} 103^{\circ} 23^{\prime} 15^{\prime \prime} \mathrm{E}$ & $\begin{array}{l}\text { Cargil palm production, Chicken food, KNM process Systems Sdn. } \\
\text { Bhd. Gas Malaysia Berhard }\end{array}$ \\
\hline
\end{tabular}

Contamination intensity was calculated to compare with the standard values of different parameters recommended by WHO (1984) and DOE, Malaysia (2000). The following equation was used to calculate contamination intensity (CI) (Rao 2012).

$\mathrm{CI}=\mathrm{C}$ standard $/ \mathrm{C}$ analysed, where, $\mathrm{C}=$ concentration.

Water quality is an indicator, where water quality parameters are compared with the respective standard value. In the study, water quality index was calculated on the basis of the concentrations of DO, BOD, COD, ammonical nitrogen, TSS and pH (Haque et al. 2010). $\times \mathrm{SIpH}$

$\mathrm{WQI}=0.22 \times \mathrm{SIDO}+0.19 \times \mathrm{SIBOD}+0.16 \times \mathrm{SICOD}+0.15 \times \mathrm{SIAN}+0.16 \times$ SITSS +0.12 where, SI indicates the sub-index function of the each given parameter and the coefficient as well as the weighting factors derived from the opinion poll.

\section{Results and Discussion}

The physical and chemical parameters are illustrated in Tables 2-5. The highest temperature $\left(36.38^{\circ} \mathrm{C}\right)$ was recorded at $\mathrm{S} 5$ in dry season owing to discharge of hot water and effluents from adjacent industries. The $\mathrm{pH}$ values were mostly slightly acidic to neutral. The EC values were found to range from $0.48-2.43 \mathrm{mS} / \mathrm{cm}$ in dry and $0.35-2.02 \mathrm{mS} / \mathrm{cm}$ in wet seasons, while DO varied from $1.06-2.56 \mathrm{mg} / \mathrm{l}$ in dry and $1.15-3.27 \mathrm{mg} / \mathrm{l}$ in wet seasons (Tables 2 and 3). Yisa and Jimoh (2010) gave the similar opinion in their studies on water quality of river Landzu, Nigeria.

The turbidity of water varied from $9.48-59.94$ NTU and $12.52-66.81$ NTU in dry and wet seasons (Tables 2 and 3). The salinity ranged from $0.14-0.91 \%$ and $0.11-0.86 \%$ in dry and wet seasons, respectively, while TDS varied from 50.48 - $173.31 \mathrm{mg} / \mathrm{l}$ (Tables 2 and 3) and TSS was between 26.08 and $190.56 \mathrm{mg} / \mathrm{l}$ in dry and between 32.01 and $215.67 \mathrm{mg} / \mathrm{l}$ in wet seasons. Water having high TSS is not pleasant to drink as well as it is harmful to health (Vinod and Chopra 2012).

The BOD of the water sample was found to vary from 41.28 - $106.73 \mathrm{mg} / \mathrm{l}$ and 41.68 - 97.03 $\mathrm{mg} / \mathrm{l}$ in dry and wet seasons, respectively (Tables 2 and 3). It was found that comparatively higher BOD was observed in dry season than in wet season due to higher temperature and lower precipitation. The COD value varied from $63.60-117.60 \mathrm{mg} / \mathrm{l}$ in dry and $46.07-102.43 \mathrm{mg} / \mathrm{l}$ in wet seasons. The high COD content indicated that the water contains higher wastes (Varunprasath and Daniel 2010). 


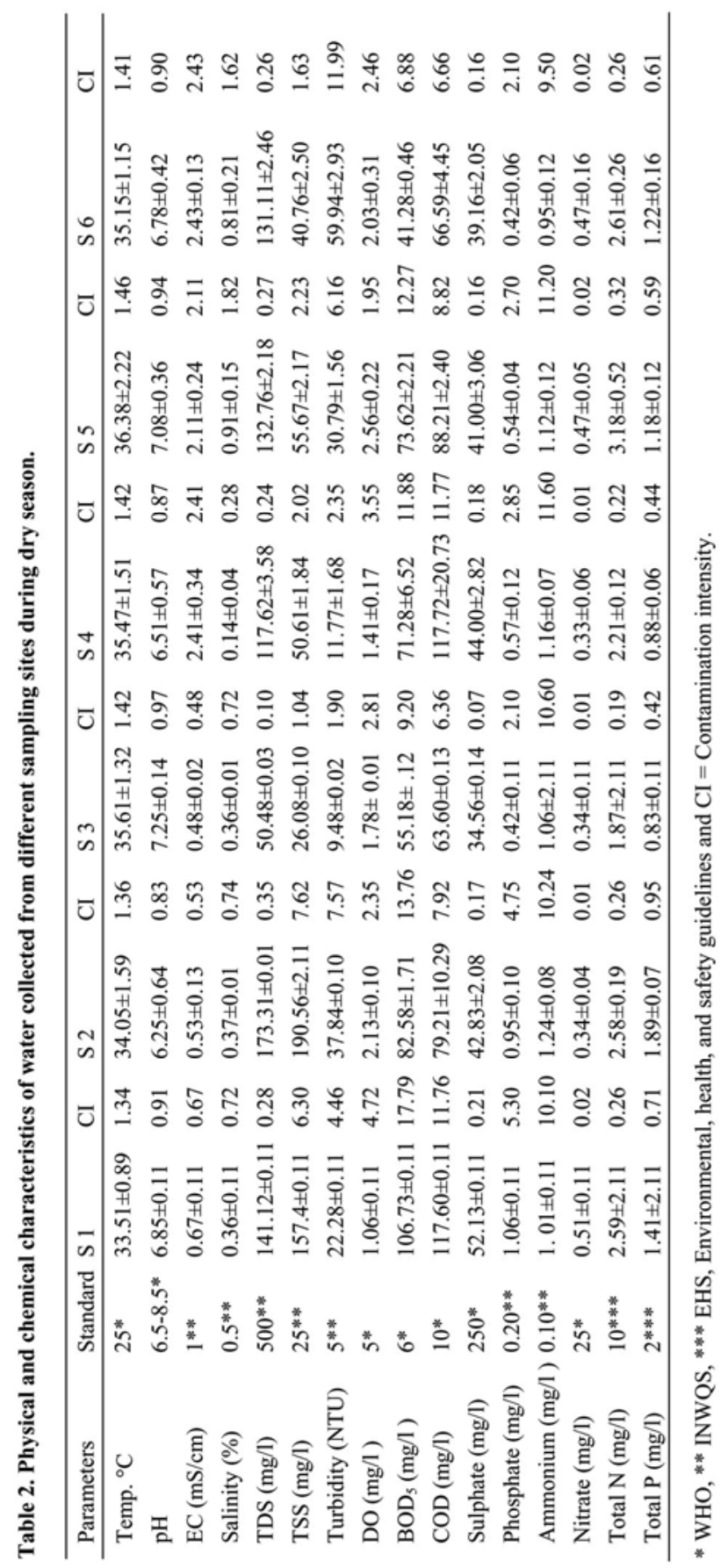




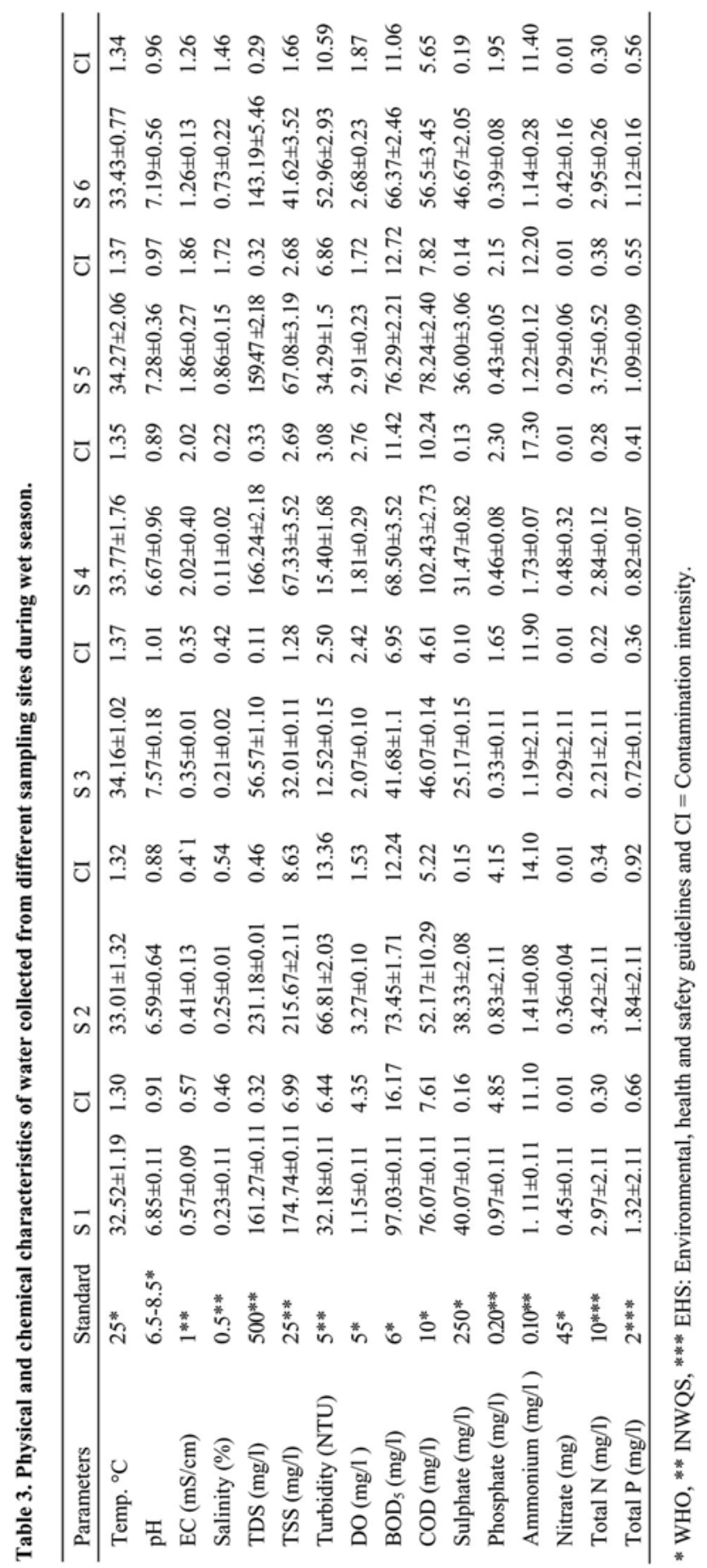




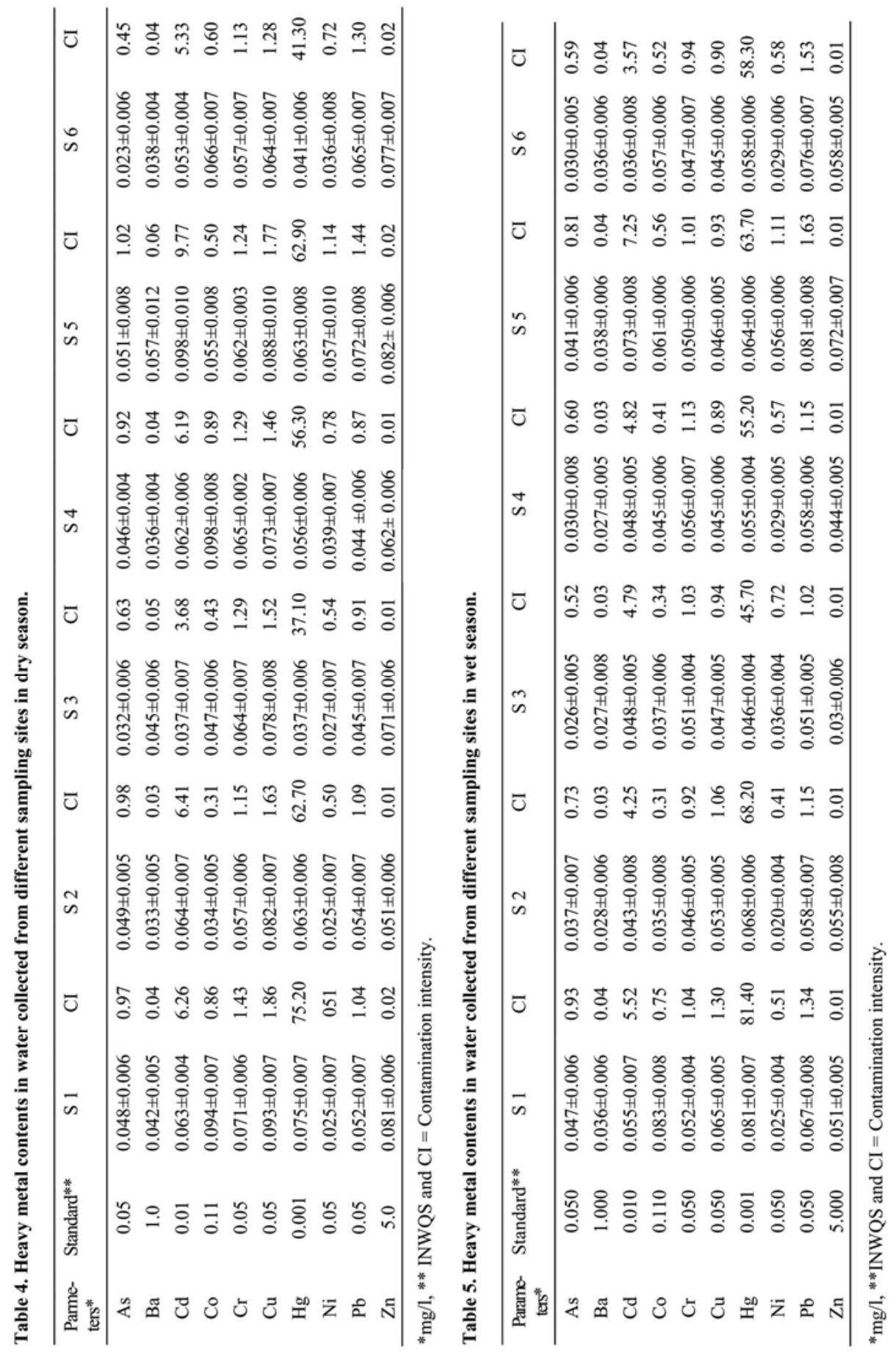


The mean $\mathrm{NH}_{3}-\mathrm{N}$ value ranged from $0.95-1.24 \mathrm{mg} / \mathrm{l}$ and $1.11-1.73 \mathrm{mg} / \mathrm{l}$ in dry and wet seasons, respectively, while $\mathrm{NO}_{3}{ }^{-}$content varied from $0.33-0.51 \mathrm{mg} / \mathrm{l}$ and $0.29-0.48 \mathrm{mg} / \mathrm{l}$ in dry and wet seasons, respectively (Tables 2 and 3). Das and Acharya (2003) conducted a research on lotic water quality, Cuttack, India and detected higher nitrate content for industrial activities. Sulfate varied from 34.56 - $52.13 \mathrm{mg} / \mathrm{l}$ and 25.17 - $46.67 \mathrm{mg} / \mathrm{l}$ in dry and wet seasons, respectively. Hem (2002) stated that sulfate is incorporated due to waste discharges, fossil fuel and combustion processes. Phosphate was $0.42-1.06 \mathrm{mg} / \mathrm{l}$ in dry and $0.33-0.97 \mathrm{mg} / \mathrm{l}$ in wet seasons. The higher amount of $\mathrm{PO}_{4}{ }^{3-}$ was due to wastes from detergent and other industries (Goltman 1975).

Arsenic (As) of all sites was found to range from $0.023-0.051 \mathrm{mg} / \mathrm{l}$ and $0.026-0.047 \mathrm{mg} / \mathrm{l}$ in dry and wet seasons, respectively, while barium $(\mathrm{Ba})$ ranged between 0.033 and $0.057 \mathrm{mg} / \mathrm{l}$ and 0.027 and $0.038 \mathrm{mg} / \mathrm{l}$ in dry and wet seasons, respectively and cadmium (Cd) ranged from 0.037 $0.098 \mathrm{mg} / \mathrm{l}$ in dry and $0.036-0.073 \mathrm{mg} / \mathrm{l}$ in wet seasons (Table 4 and 5). Due to dry condition and the lesser precipitation, industrial activities and especially the availability of the inflow of effluents caused the contamination of heavy metals like $\mathrm{Cd}, \mathrm{Cr}, \mathrm{Pb}, \mathrm{Zn}, \mathrm{Ni}$ and $\mathrm{Cu}$ (Wogu and Okaka 2011). Cobalt (Co) ranged from $0.034-0.098 \mathrm{mg} / \mathrm{l}$ and $0.035-0.083 \mathrm{mg} / \mathrm{l}$ in dry and wet seasons, respectively (Tables 4 and 5). Chromium $(\mathrm{Cr})$ varied from $0.057-0.071 \mathrm{mg} / \mathrm{l}$ and $0.046-0.056$ $\mathrm{mg} / \mathrm{l}$ in dry and wet seasons, respectively. Cupper $(\mathrm{Cu})$ concentration ranged from $0.064-0.093$ $\mathrm{mg} / \mathrm{l}$ and $0.045-0.065 \mathrm{mg} / \mathrm{l}$ in dry and wet seasons, respectively (Table 4 and 5). Mercury (Hg) ranged from $0.037-0.075 \mathrm{mg} / \mathrm{l}$ and $0.046-0.081 \mathrm{mg} / \mathrm{l}$ in dry and wet seasons, and zinc (Zn) was found to vary from $0.051-0.081 \mathrm{mg} / \mathrm{l}$ in dry and $0.030-0.072 \mathrm{mg} / \mathrm{l}$ in wet seasons (Tables 4 and 5). Ram et al. (2003) detected high $\mathrm{Hg}$ levels due to dumping of effluents from different industries. Nickel (Ni) varied from $0.025-0.057 \mathrm{mg} / \mathrm{l}$ and $0.020-0.056 \mathrm{mg} / \mathrm{l}$ in dry and wet seasons, respectively, while lead $(\mathrm{Pb})$ varied from $0.044-0.072 \mathrm{mg} / \mathrm{l}$ and $0.051-0.081 \mathrm{mg} / \mathrm{l}$ in dry and wet seasons, respectively (Tables 4 and 5). Haque et al. (2009) recorded extremely higher $\mathrm{Cr}$ and $\mathrm{Pb}$ in surface and groundwater of the industrial areas of Karachi, Pakistan.

Table 6. Water quality parameters for WQI at different sampling sites in dry season.

\begin{tabular}{cccccccc}
\hline Sites & $\begin{array}{c}\text { DO } \\
(\%)\end{array}$ & $\begin{array}{c}\text { BOD } \\
(\mathrm{mg} / \mathrm{l})\end{array}$ & $\begin{array}{c}\text { COD } \\
(\mathrm{mg} / \mathrm{l})\end{array}$ & $\begin{array}{c}\text { Ammonical } \\
\text { nitrogen }(\mathrm{mg} / \mathrm{l})\end{array}$ & $\begin{array}{c}\text { TSS } \\
(\mathrm{mg} / \mathrm{l})\end{array}$ & $\mathrm{pH}$ & WQI \\
\hline S 1 & 13.84 & 106.73 & 117.60 & 1.01 & 157.4 & 6.85 & 37.75 \\
S 2 & 28.69 & 82.58 & 79.21 & 1.24 & 190.56 & 6.25 & 40.51 \\
S 3 & 23.92 & 55.18 & 63.60 & 1.06 & 26.08 & 7.42 & 49.72 \\
S 4 & 18.74 & 71.18 & 117.72 & 1.16 & 50.61 & 6.51 & 43.70 \\
S 5 & 34.28 & 71.62 & 88.21 & 1.12 & 55.67 & 7.08 & 48.61 \\
S 6 & 27.39 & 41.28 & 66.59 & 0.96 & 40.76 & 6.78 & 51.10 \\
\hline
\end{tabular}

WQI = Water quality index, Class I = > 91.76; Class II = 75.36 - 91.75; Class III = 51.68 - 75.35; Class IV = 29.61 - 51.67; Class V $=<29.60$.

The CI was comparatively higher in dry than in wet season (Tables 2 to 5). It was found that temperature, turbidity, BOD, COD, TSS, DO, ammonical nitrogen and phosphate showed $>1.0$, while, TDS, sulfate, nitrate, TN and TP were found $<1.0$ and $\mathrm{pH}$ was $>6.0$ in both seasons. The CI value of EC showed $>1.0$ at S 4, S 5 and S 6, and salinity was $>1.0$ at S 5 and S 6 , while it was $<1.0$ for rest of the sites for both EC and salinity during two seasons. In addition, CI of $\mathrm{Ni}$ at S 5 was $>1.0$ and rest were $<1.0$ in both seasons, while As, Ba, Co and $\mathrm{Zn}$ were found $<1.0$ in both seasons. The result revealed that $\mathrm{Hg}$ and $\mathrm{Cd}$ were very high. It was exhibited that $\mathrm{Hg}$ ranged from 
37.10 to 81.40 , while, Cd varied from 3.57 to 9.77. Water samples of all sites in both seasons were categorized into Class IV (highly polluted) (Tables 6 and 7).

Table 7. Water quality parameters for WQI at different sampling sites in wet season.

\begin{tabular}{cccccccc}
\hline Sites & $\begin{array}{c}\text { DO } \\
(\%)\end{array}$ & $\begin{array}{c}\text { BOD } \\
(\mathrm{mg} / \mathrm{l})\end{array}$ & $\begin{array}{c}\text { COD } \\
(\mathrm{mg} / \mathrm{l})\end{array}$ & $\begin{array}{c}\text { Ammonical } \\
\text { nitrogen }(\mathrm{mg} / \mathrm{l})\end{array}$ & $\begin{array}{c}\text { TSS } \\
(\mathrm{mg} / \mathrm{l})\end{array}$ & $\mathrm{pH}$ & WQI \\
\hline S 1 & 15.10 & 97.03 & 76.07 & 1.11 & 174.74 & 6.85 & 38.54 \\
S 2 & 43.51 & 73.45 & 52.17 & 1.41 & 215.67 & 6.59 & 45.52 \\
S 3 & 27.91 & 41.68 & 46.07 & 1.19 & 32.01 & 7.97 & 51.21 \\
S 4 & 24.34 & 68.50 & 102.43 & 1.73 & 67.33 & 6.67 & 42.95 \\
S 5 & 38.83 & 76.29 & 78.24 & 1.22 & 67.08 & 7.28 & 49.06 \\
S 6 & 35.84 & 66.37 & 55.50 & 1.14 & 41.62 & 7.19 & 51.17 \\
\hline
\end{tabular}

WQI = Water quality index, Class I = > 91.76; Class II = 75.36 -91.75 ; Class III = 51.68 - 75.35; Class IV = 29.61 - 51.67; Class V $=<29.60$.

The CI, pollution level, classification of water indicated that the studied water having higher contaminant level especially, BOD, $\mathrm{COD}, \mathrm{NH}_{3}-\mathrm{N}$, phosphate, $\mathrm{Pb}, \mathrm{Cd}, \mathrm{Cr}, \mathrm{Cu}$ and $\mathrm{Hg}$ and lower DO. It also revealed that emphasis should be given on proper treatment of industrial effluents and wastes to reduce the pollution status.

\section{Acknowledgement}

Authors are grateful to the University Malaysia Pahang and the Faculty of Civil Engineering and Earth Resources for their support and funding through the research project RDU 1203122 and GRS 130322.

\section{References}

Abramov VO, Abramova AV, Keremetin PP, Mullakaev MS, Vexler GB, Timothy J and Mason TJ 2014. Ultrasonically improved galvano-chemical technology for the remediation of industrial wastewater. Ultrason. Sonochem. 21: 812-818.

APHA 2013. Standard methods of water and wastewater analysis. (22th Ed.), Washington.

Changhao LB and Zhans K 2013. Industrial ecology and water utilization of the marine chemical industry. A case study of Hai Hua Group (HHG), Chine, Resources, conservation and recycling 70: 78-85.

Das J and Acharya BC 2003. Hydrology and assessment of lotic water quality in Cuttack city. Ind. J. Water, Air and Soil Poll. 150: 163-175.

DOE. 2000. Interim National Water Quality Standards (INWQS) for Malaysia. Kuala Lumpur, Department of Environment.

Golterman HL 1975. Physiological Limnology. Elsevier. Amsterdam,

Haque MA, Huang YF and Lee TS 2010. Seberang Perai rice scheme irrigation water quality assessment. J. Instit. Eng. Malaysi. 71: 42-49.

Haque UN, Arain MA, Haque Z, Badar N and Mughal N 2009. Drinking water contamination by chromium and lead in industrial lands of Karachi. J. Pak. Med. Assoc. 59(5): 270-274.

Hem JD 2002. Study and Interpretation of the Chemical Characteristics of natural water (3rd Ed.). United States geological survey, Washington.

Ram A, Rokade MA, Borole DV and Zingde MD 2003. Mercury in sediments of Ulhas estuary. Mar. poll. Bull. 46: 846-857.

Rao S (Ed.) 2012. PIG - A numerical index for dissemination of groundwater contamination zones. Hydrological Processes. John Wiley \& Sons. 
Sujaul I, Hossain M Nasly MA and Sobahan MA 2013. Effect of industrial pollution on the spatial variation of surface water quality. Am. J. Environ. Sci. 9: 120-129.

Syukor A, Zularisam ABW, Ideris Z, Ismid MM, Suryati SSM and Hasmanie AH 2013. Treatment of industrial wastewater at Gebeng area using Eichornia crassippes, Pistia stratiotes and Salvinia molesta. Adv. Environ. Biol. 7: 3802-3807.

Varunprasath K and Daniel NA 2010. Comparison studies of three fresh water rivers (Cauvery, Bhavani and Noyyal) in Tamilnadu, India. Iranica J. Ener. Environ. 1: 315-320.

Vinod K and Chopra AK 2012. Monitoring of physicochemical and microbiological characteristics of municipal wastewater at treatment plant, Haridwar city. India. J. Environ. Sci. Technol. 5: 109-118.

WHO 1984. Guide lines for drinking water quality. Vol. 2. Health criteria and other supporting information. WHO, Geneva. pp. 85-315.

Wogu MD and Okaka CE 2011. Pollution studies on Nigerian rivers: heavy metals in surface water of Warri river, Delta State. J. Biodiver. Environ. Sci. 1(3): 7-12.

Yisa J and Jimoh T 2010. Analytical studies on water quality index of river Landzu. Am. J. Applied Sci. 7: 453-458.

(Manuscript received on 28 April, 2014; revised on 4 August, 2014) 